\title{
QUALITY OF COLOSTRAL PASSIVE IMMUNITY AND PATTERN OF SERUM PROTEIN FLUCTUATION IN NEWBORN CALVES
}

\author{
Patricia Pauletti; Raul Machado Neto*; Irineu Umberto Packer; Raul Dantas D'Arce; Rosana \\ Bessi
}

USP/ESALQ - Depto. de Produção Produção Animal, C.P. 9 - 13418-900 - Piracicaba, SP - Brasil. *Correspondent author <rmachado@esalq.usp.br>

\begin{abstract}
Immunity acquired by newborn animals is known as passive immunity, and for ruminants, antibody acquisition depends on the ingestion and absorption of adequate amounts of immunoglobulins from colostrum. This study relates different initial levels of acquired passive protection and serum total protein (TP) and immunoglobulin G (IgG). Serum immunoglobulin concentration and total protein were evaluated for female Holstein calves in the first sixty days of life. Animals were separated into three groups according to their initial level of passive immunity: group 1- animals with a low level of passive immunity (below $20 \mathrm{mg} \mathrm{mL}^{-1}$ ); group 2- animals with a medium level (between 20 and $30 \mathrm{mg} \mathrm{mL}^{-1}$ ), and group 3- animals with a high level (above $30 \mathrm{mg} \mathrm{mL}^{-1}$ ). Serum total protein was determined through the biuret method and IgG was determined by radial immunodiffusion. Data were analyzed as a completely randomized, split-plot statistical design. Fluctuation of the variables along the experimental period was determined through non-linear regression by the DUD method (PROC NLIN - Non Linear SAS). Animals with low antibody acquisition started to produce antibodies earlier, reflecting a compensatory synthesis. On the other hand, animals having adequate levels exhibited an extended period of immunoglobulin catabolism and the beginning of the endogenous phase was delayed. Regardless initial levels, the fluctuations in IgG contents occurred around adequate physiological concentrations, ranging from 20 to $25 \mathrm{mg} \mathrm{mL}^{-1}$.
\end{abstract}

Key words: colostrum, dairy calves, antibodies

\section{QUALIDADE DA IMUNIDADE PASSIVA COLOSTRAL E PERFIL DE VARIAÇÃO DE PROTEÍNAS SÉRICAS EM BEZERROS NEONATOS}

\begin{abstract}
RESUMO: A imunidade adquirida pelos recém-nascidos é denominada passiva e no caso dos ruminantes a aquisição de anticorpos depende da ingestão e absorção de quantidades adequadas de imunoglobulinas do colostro. Este trabalho relaciona diferentes teores iniciais de proteção passiva adquirida com o comportamento das variáveis proteína total (PT) e imunoglobulina G séricas (IgG). Os teores séricos de IgG e PT foram avaliados em bezerras da raça Holandesa do nascimento até 60 dias de idade. Os animais foram agrupados de acordo com a concentração inicial de imunoglobulinas séricas adquiridas: grupo 1- animais com baixo nível de imunidade passiva (até $20 \mathrm{mg} \mathrm{mL}^{-1}$ ); grupo 2- animais com nível médio de imunidade passiva (de $20 \mathrm{a}$ $30 \mathrm{mg} \mathrm{mL}^{-1}$ ) e grupo 3- animais com alto nível de imunidade passiva (acima de $30 \mathrm{mg} \mathrm{mL}^{-1}$ ). As amostras séricas foram analisadas quanto a proteína total pelo método de biureto e para quantificação de $\operatorname{IgG}$ foi utilizado o método de imunodifusão radial. Os teores séricos de IgG e PT foram avaliados em um delineamento experimental inteiramente casualizado em parcelas subdivididas no tempo. Para determinar o comportamento dessas variáveis ao longo do período experimental, foram traçadas regressões não-lineares pelo método de DUD, procedimento PROC NLIN do SAS. Nos animais com baixa aquisição inicial de anticorpos verificouse uma produção de anticorpos mais precoce. Já para os animais com níveis adequados de anticorpos verificouse uma fase de catabolismo prolongada das imunoglobulinas e um início mais tardio da síntese endógena de anticorpos. Independente dos níveis iniciais, as flutuações dos teores de $\operatorname{IgG}$ ocorreram em intervalo de concentrações fisiologicamente adequadas, ou seja de 20 a $25 \mathrm{mg} \mathrm{mL}^{-1}$.

Palavras-chave: colostro, bezerros leiteiros, anticorpos
\end{abstract}

\section{INTRODUCTION}

Survival and healthiness of newborn animals directly depend upon the acquisition of maternal antibodies. In the case of ruminants, the newborn relies on the ingestion of colostrum to obtain immunoglobulins (Brambell, 1958; Jeffcott, 1972).

The serum immunoglobulin content found in calves after receiving colostrum is quite variable. The absorption of antibodies by newborn calves can 
be affected by many factors, particularly by the time elapsed from birth to the first ingestion of colostrum and by their concentration in immunoglobulins (Edwards et al., 1982; Besser et al., 1991; Quigley et al., 1995; Ramin et al., 1996; Machado Neto et al., 1997; Morin et al., 1997).

After the absorptive period, the animal undergoes a transitional stage during which stops benefiting from mother-acquired antibodies and starts to respond actively to environment challenges. However, animals presenting different initial levels of antibodies acquired from colostrum respond differently to the endogenous production (Husband \& Lascelles, 1975; Machado Neto \& Packer, 1986; Baracat et al., 1997; Aldridge et al., 1998).

The objective of this work was to establish a relation between different initial levels of acquired passive protection and variables serum total protein (TP) and immunoglobulin $\mathrm{G}$ (IgG), and to define behavior patterns for their curves, during the first 60 days of life, aiming to facilitate the development of newborn calf management alternatives.

\section{MATERIAL AND METHODS}

Fifty nine female Holstein calves were utilized in this study, distributed in three groups according to their initial concentration of acquired serum immunoglobulins at 24 hours after birth: group 1- animals with low level of passive immunity (up to $20 \mathrm{mg} \mathrm{mL}^{-1} \mathrm{IgG}$ ); group 2medium level (between 20 and $30 \mathrm{mg} \mathrm{mL}^{-1} \mathrm{IgG}$ ); and group 3- high level (above $30 \mathrm{mg} \mathrm{mL}^{-1} \mathrm{IgG}$ ).

Blood samples were collected from calves external jugular vein, at the following ages: $1 ; 5 ; 10 ; 15 ; 17$; $20 ; 25 ; 30 ; 35 ; 40 ; 45 ; 50$ and 60 days after birth. The serum, separated after centrifugation, was maintained at $-20^{\circ} \mathrm{C}$ until analysis. Serum samples were analyzed for serum total protein (TP) by the biuret method (Reinhold, 1953); serum immunoglobulin G (IgG) was quantified through the radial immunodiffusion method described by Mancini et al. (1965).

A completely randomized experimental design with split-plots in time was adopted, and the effect of the initial immunoglobulin levels was attributed to plots, with the measurements repeated in time considered as subplots. Correlation, Pearson and Sperman analyses were carried out to verify associations of interest between the TP and IgG variables. Non-linear regressions were plotted for the groups to determine the behavior of variables TP and IgG during the experimental period; these regressions proved to be more suitable for this type of variable; one curve was obtained for each group. The chosen model was: $\mathbf{Y}=\mathbf{L}+\mathbf{U} *(\mathbf{R}-\mathbf{I D})+\mathbf{V} *(\mathbf{I D}-\mathbf{R})$, where $\mathbf{Y}=$ variable's concentration, $\mathbf{I D}=$ animal age (days), $\mathbf{L}=$ point of minimum concentration, $\mathbf{U}=$ slope during the period that preceded the point of minimum concentration, $\mathbf{V}=$ slope during the period after the point of minimum concentration, $\mathbf{R}=$ age at the point of minimum concentration.
The DUD method, an iterative process to reach the convergence criterion, was then applied by means of the PROC NLIN (NonLinear) SAS (1999) procedure. The general curve model selected corresponded to that which best fitted the serum variable data. Since it is a non-linear model, it was necessary to utilize an iterative process to solve the equations. It requires the selection of initial values as starting point to iterate according to some preestablished criterion (Diaz, 1992). However, no algorithm exists to determine adequate initial values, and the body of knowledge suggested by previous research had to be resorted to. There were no values available in the literature for the proposed model, so the initial values for the parameters were selected based on the mean values obtained for each group.

\section{RESULTS AND DISCUSSION}

Animals presenting adequate concentrations of passive immunoglobulins modulate the immune response by delaying the production of endogenous immunoglobulin, while those having low contents will speed up their active production as a response to environmental challenges (Husband \& Lascelles, 1975; Logan et al., 1974; Ribeiro et al., 1983; Machado Neto \& Packer, 1986). The decrease in IgG concentration during the first month after birth for groups 2 and 3 (Table 1; Figure 1), resulted from the catabolism of proteins passively acquired from colostrum. The age at the point of minimum concentration (R) was 22.290 and 26.019 day for groups 2 and 3, respectively; the confidence interval analysis indicated that the groups did not differ in relation to age at the point of minimum concentration for the variable IgG. Many studies report that the endogenous production of antibodies does not contribute towards increasing the amounts of serum antibodies until two weeks after birth, since this fraction is lower than the rate of catabolism of maternal antibodies (Husband et al., 1972; Daniele et al., 1994a; Rajala \& Castren, 1995; Baracat et al., 1997).

For group 3, parameter $\mathrm{V}$ was non significant by the confidence interval analysis. This result indicates the occurrence of a plateau between the date of minimum concentration $\mathrm{R}=26.019$ and the end of the experimental period. This fact is a consequence of the high initial concentration of acquired immunoglobulin, thus delaying the endogenous production of antibodies. For group 1, however, there was no initial peak of IgG followed by a reduction, and this can be justified by the initial condition, which determined a reduced catabolic activity and an early endogenous production of antibodies. Animals of high serum IgG contents, correlated with high concentrations of total serum protein, would delay the endogenous synthesis of immunoglobulins, while animals of low initial values would accelerate their production (Logan et al., 1974; Husband \& Lascelles, 1975; Machado Neto \& Packer, 1986). 
Table 1 - Mean predicted values of immunoglobulin concentrations for the experimental groups.

\begin{tabular}{|c|c|c|c|c|c|}
\hline Age & Group 1 & Age & Group 2 & Age & Group 3 \\
\hline day & $\mathrm{mg} \mathrm{mL}^{-1}$ & day & $\mathrm{mg} \mathrm{mL}^{-1}$ & day & $\mathrm{mg} \mathrm{mL}^{-1}$ \\
\hline 1 & 10.321 & 1 & 26.403 & 1 & 37.819 \\
\hline 5 & 10.321 & 5 & 24.707 & 5 & 35.041 \\
\hline 10 & 10.321 & 10 & 22.587 & 10 & 31.567 \\
\hline 15 & 10.321 & 15 & 20.467 & 15 & 28.093 \\
\hline 17 & 10.321 & 17 & 19.619 & 17 & 26.704 \\
\hline $19.592 *$ & 10.321 & 20 & 18.347 & 20 & 24.620 \\
\hline 20 & 10.441 & $22.290 *$ & 17.376 & 25 & 21.146 \\
\hline 25 & 11.914 & 25 & 17.934 & $26.019 *$ & 20.438 \\
\hline 30 & 13.387 & 30 & 18.963 & 30 & 20.438 \\
\hline 35 & 14.860 & 35 & 19.992 & 35 & 20.438 \\
\hline 40 & 16.333 & 40 & 21.021 & 40 & 20.438 \\
\hline 45 & 17.807 & 45 & 22.049 & 45 & 20.438 \\
\hline 50 & 19.280 & 50 & 23.078 & 50 & 20.438 \\
\hline 60 & 22.226 & 60 & 25.136 & 60 & 20.438 \\
\hline
\end{tabular}

Group 1: low level $=$ up to $20 \mathrm{mg} \mathrm{mL}^{-1} \mathrm{IgG}$

Group 2: medium level = between 20 and $30 \mathrm{mg} \mathrm{mL}^{-1} \mathrm{IgG}$

Group 3: high level = above $30 \mathrm{mg} \mathrm{mL}^{-1} \mathrm{IgG}$.

*Age at the point of minimum concentration $(\mathrm{R})$

Table 2 - Mean predicted values of serum total protein concentration in the experimental groups.

\begin{tabular}{|c|c|c|c|c|c|}
\hline Age & Group 1 & Age & Group 2 & Age & Group 3 \\
\hline day & g $100 \mathrm{~mL}^{-1}$ & day & $\mathrm{mg} \mathrm{mL}^{-1}$ & day & $\mathrm{mg} \mathrm{mL^{-1 }}$ \\
\hline 1 & 6.259 & 1 & 7.617 & 1 & 8.998 \\
\hline 5 & 6.259 & 5 & 7.485 & 5 & 8.613 \\
\hline 10 & 6.259 & 10 & 7.320 & 10 & 8.132 \\
\hline 15 & 6.259 & 15 & 7.155 & 15 & 7.651 \\
\hline 17 & 6.259 & 17 & 7.089 & 17 & 7.458 \\
\hline 20 & 6.259 & 20 & 6.990 & 20 & 7.169 \\
\hline 25 & 6.259 & $22.845^{*}$ & 6.896 & $20.358 *$ & 7.135 \\
\hline $29.999 *$ & 6.259 & 25 & 6.956 & 25 & 7.211 \\
\hline 30 & 6.259 & 30 & 7.095 & 30 & 7.292 \\
\hline 35 & 6.398 & 35 & 7.233 & 35 & 7.373 \\
\hline 40 & 6.538 & 40 & 7.372 & 40 & 7.455 \\
\hline 45 & 6.678 & 45 & 7.511 & 45 & 7.536 \\
\hline 50 & 6.818 & 50 & 7.649 & 50 & 7.617 \\
\hline 60 & 7.098 & 60 & 7.927 & 60 & 7.780 \\
\hline
\end{tabular}

Group 1: low level $=$ up to $20 \mathrm{mg} \mathrm{mL}^{-1} \mathrm{IgG}$

Group 2: medium level $=$ between 20 and $30 \mathrm{mg} \mathrm{mL}^{-1} \mathrm{IgG}$

Group 3: high level $=$ above $30 \mathrm{mg} \mathrm{mL}^{-1} \mathrm{IgG}$

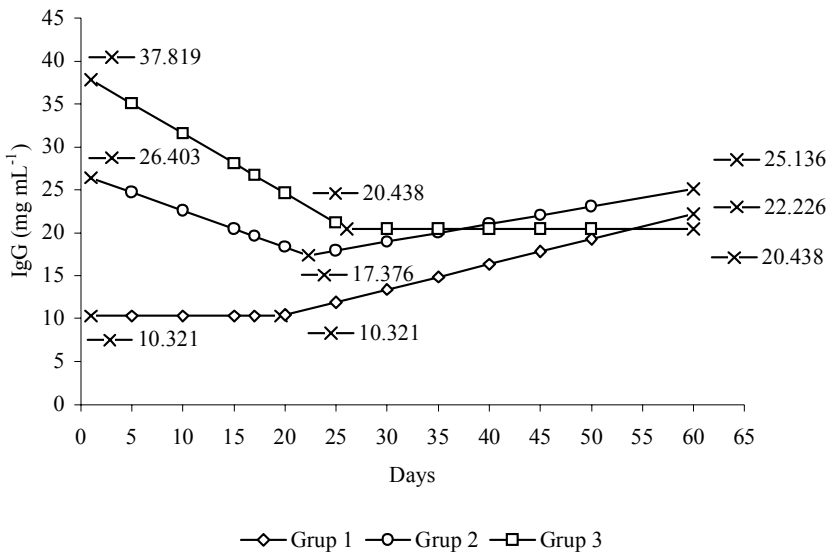

Figure 1 - Average fluctuation of seric IgG concentration, with adjusted values.

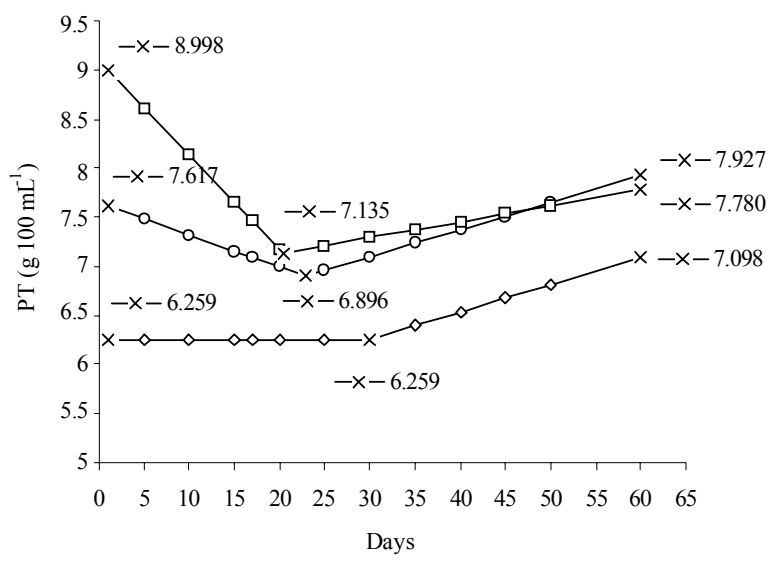

$\multimap$ Grup $1 \multimap$ Grup $2 \multimap-$ Grup 3

Figure 2 - Average fluctuation of total protein concentration, with adjusted values. 
The serum TP and IgG variables presented similar behavior $(P<0.0001)$, considering the entire experimental period, with $\mathrm{r}=0.788$; this was also observed by other authors (Daniele et al., 1994a; Baracat et al., 1995). For groups 2 and 3 there was a decrease in serum TP concentration in the $1^{\text {st }}$ month after birth (Table 2, Figure 2), and this was a consequence of the catabolism of antibodies passively acquired from colostrum over the group of serum proteins, indicating a protein catabolic process, a fact already observed by several authors (Machado Neto \& Packer, 1986; Daniele et al., 1994b; Baracat et al., 1995; Bessi, 1996).

The point of minimum concentration of TP (L) for group 2 was $6.896 \mathrm{~g} 100 \mathrm{~mL}^{-1}$ while for group $3 \mathrm{~L}$

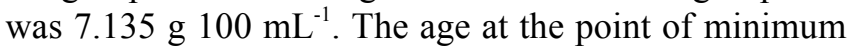
concentration (R) for group 2 was 22.845 day whereas for group $3 \mathrm{R}$ was 20.358 day. The range of variation of $\mathrm{L}$ and $\mathrm{R}$ values, expressed by the confidence interval, demonstrated that the groups did not differ among themselves. In group 1, however, no point of minimum concentration for TP was detected. This variable increased through the experimental period as a consequence of the compensatory synthesis of IgG for animals with low initial concentration of serum antibodies. The greater the initial value of serum IgG, the longer the period of proteic catabolism tends to last. Consequently, the inflexion point follows the same trend, since colostrum-acquired immunoglobulins are the most important fraction that determines fluctuation in the serum TP variable, at the beginning of animal's life.

Regardless the initial levels, fluctuations in IgG contents occurred toward physiologically adequate concentrations, i.e., between 20 and $25 \mathrm{mg} \mathrm{mL}^{-1}$. In addition, the initial levels of IgG are directly related to the beginning of the endogenous production of antibodies and influence the behavior of serum IgG and TP of animals in their first months of life.

\section{REFERENCES}

ALDRIDGE, B.M.; McGUIRK, S.M.; LUNN, D.P. Effect of colostral ingestion on immunoglobulin-positive cells in calves. Veterinary Immunology and Immunopathology, v.62, p.51-64, 1998.

BARACAT, R.S.; MACHADO NETO, R.; DANIELE, C.; BESSI, R.; PACKER, I.U. Fornecimento prolongado de colostro e proteção passiva em bezerros recém-nascidos. Pesquisa Agropecuária Brasileira, v.32, p.215-1220, 1997.

BARACAT, R.S.; MACHADO NETO, R.; DANIELE, C.; BESSI, R.; PACKER, I.U. Influência do fornecimento prolongado de colostro sobre a flutuação de proteínas séricas em bezerros com diferentes níveis de imunidade passiva sérica. Scientia Agricola, v.52, p.537-542, 1995.

BESSER, T.E.; GAY, C.C.; PRITCHETT, L. Comparison of three methods of feeding colostrum to dairy calves. Journal of the American Veterinary Medical Association, v.198, p.419-422, 1991.

BESSI, R. Efeito de selênio e vitamina E sobre o desenvolvimento imunológico de bezerros. Piracicaba: USP/ESALQ, 1996. 102p. (Dissertação - Mestrado)

BRAMBELL, F.W.R. The passive immunity of the young mammal. Biological Reviews, v.33, p.488-531, 1958.
DANIELE, C.; MACHADO NETO, R.; BARACAT, R.S.; BESSI, R.; PACKER, I.U. Efeito de diferentes manejos no fornecimento prolongado de colostro sobre o comportamento imunológico e desempenho de bezerros leiteiros recém-nascidos. Revista da Sociedade Brasileira de Zootecnia, v.23, p.211-222, 1994a.

DANIELE, C.; MACHADO NETO, R.; BARACAT, R.S.; BESSI, R.; PACKER, I.U. Efeito de diferentes manejos de fornecimento prolongado de colostro sobre os níveis de proteína e albumina séricas e desempenho de bezerros recém-nascidas. Scientia Agricola, v.5, p.381-388, 1994b.

DIAZ, M.D.P. Estudo da lei de auto-desbate através de ajuste de modelos lineares e não-lineares, em povoamentos de Eucalyptus grandis, no Estado de São Paulo. Piracicaba: USP/ESALQ, 1992. 92p. (Dissertação - Mestrado)

EDWARDS, S.A.; BROOM, D.M.; COLLIS, S.C. Factors affecting levels of passive immunity in dairy calves. British Veterinary Journal, v.138, p.233-240, 1982.

HUSBAND, A.J.; BRANDON, M.R.; LASCELLES, A.K. Absorption and endogenous production of immunoglobulins in calves. The Australian Journal of Experimental Biology and Medical Science, v.50, p. 491498, 1972.

HUSBAND, A.J.; LASCELLES, A.K. Antibody responses to neonatal immunization in calves. Research in Veterinary Science, v.18, p.201207, 1975.

JEFFCOTT, L.B. Passive immunity and its transfer with special reference to the horse. Biological Reviews, v.47, p.439-464, 1972.

LOGAN,E.F.; McBEATH, D.G.; LOWMAN, B.G. Quantitative studies of serum immunoglobulin levels in sucled calves from birth to five weeks. Veterinary Record, v.94, p.367-370, 1974.

MACHADO NETO, R.; PACKER, I.U. Flutuação de imunoglobulina sérica em bezerros da raça holandesa submetidos a diferentes regimes de aleitamento. Revista da Sociedade Brasileira de Zootecnia, v.15, p.439447, 1986.

MACHADO NETO, R.; PACKER, I.U.; BONILHA, L.M.; FIGUEIREDO, L.A.; RAZZOK, AG.; CÂNDIDO, J.G. Concentração de IgG sérica em bezerros das raças Nelore, Guzerá, Gir e Caracu. 2. Efeitos sobre crescimento e mortalidade até a desmama. Revista Brasileira de Zootecnia, v.26, p.920-923, 1997.

MANCINI, G.; CARBONARA, A.O.; HERMANS, J.F. Immunochemical quantitation of antigens by single radial immunodiffusion. Immunochemistry, v.2, p.253-254, 1965.

MORIN, D.E.; McCOY, G.C.; HURLEY, W.L. Effects of quality, quantity, and timing of colostrum feeding and addition of a dried colostrum supplement on immunogloblin G1 absorption in Holstein bull calves. Journal of Dairy Science, v.80, p.747-753, 1997.

QUIGLEY, J.D; MARTIN, K.R; BEMIS, D.A; POTGIETER, L.N.D.; REINEMEYER, C.R.; ROHRBACH, B. W; DOWLEN, H.H.; LAMAR, K.C. Effects of housing and colostrum feeding on serum immunoglobulins growth, and fecal scores of Jersey calves. Journal of Dairy Science, v.78, p.893-901, 1995.

RAJALA, P.; CASTRÉN, H. Serum immunoglobulins concentrations and health of dairy calves in two management systems from birth to 12 weeks of age. Journal of Dairy Science, v.78, p.2737-2744, 1995.

RAMIN, A.G.; DANIEL, R.C.W.; FENWICK, D.C.; VERRAL, R.G. Serum immunoglobulin concentrations in young dairy calves and their relationships with weight gain, onset of puberty and pelvic area at 15 months of age. Livestock Productions Science, v.45, p.155-162, 1996.

REINHOLD, J.G. Total protein, albumin and globulin. In: REINER, M. Standard methods of clinical chemistry. New York: Academic Press, 1953, v. 1 , p. 88 .

RIBEIRO, M.F.B.; BELEM, P.A.D.; PATARROYO, J.H.S.; FARIA, J.E. de. Hipogamaglobulinemia em bezerros. Arquivo Brasileiro de Medicina Veterinária e Zootecnia, v.35, p.537-546, 1983.

SAS INSTITUTE S/A. SAS/STAT: user's guide. Release 8.ed. Cary: Statistical Analysus System Institute, 1999. 1028p.

Received March 6, 2002

Accepted April 28, 2003 